\title{
ESTIMATION OF ALLUVIAL RECHARGE IN THE SEMIARID
}

\section{TAFNES S. ANDRADE ${ }^{1}$, SUZANA M. G. L. MONTENEGRO ${ }^{2}$, ABELARDO A. DE A. MONTENEGRO ${ }^{3}$, DIOGO F. B. RODRIGUES ${ }^{4}$}

\begin{abstract}
In areas where there is irrigated agriculture, the recuperation of water reserves in alluvial aquifers may occur preferentially due to precipitation. Recharging can be evaluated from variation information of water depth measured in piezometers or observation wells. Thus, the aim of this research is to study the recharge in the alluvial aquifer formed by the Mimoso temporary stream in the semiarid region of Pernambuco (PE), Brazil, using the method of the fluctuation of the water level. This system is typical on the Brazilian Northeast semiarid region, using groundwater for domestic supply and for irrigation on small scale agriculture. Monthly potentiometric levels and rainfall data were used. The selected period for the study, from January 2002 to October 2009, involved extreme events of flooding and droughts as well as regular years, providing a better understanding of the behavior of the alluvial recharge. It was found that the system responds significantly to precipitation events. It was also observed that even with different soil textures in the study area, recharge factors were not significantly different. The study provided a better understanding of the behavior of aquifer recharge and its relationship with the soil and the rainfall events in the region.
\end{abstract}

KEYWORDS: recharge factor, groundwater, monitoring.

\section{ESTIMATIVA DE RECARGA EM ALUVIÃO NO SEMIÁRIDO}

RESUMO: Em áreas onde se pratica agricultura irrigada, a recuperação das reservas hídricas do aquífero aluvial pode ocorrer devida, preferencialmente, à precipitação. A recarga pode ser avaliada a partir de informação da variação da profundidade da água. Desta forma, o objetivo do presente trabalho é estudar a recarga no aquífero aluvial formado pelo riacho temporário do Mimoso, na região semiárida de Pernambuco, utilizando o método da flutuação do nível da água. Esse sistema é típico de sistemas do semiárido do Nordeste do Brasil, com uso da água subterrânea para abastecimento de populações difusas que residem nesses vales aluviais e para irrigação em agricultura familiar ou de pequena escala. Foram utilizados dados mensais do monitoramento dos níveis potenciométricos e dados de precipitação pluviométrica. O período selecionado, janeiro de 2002 a outubro de 2009, envolveu eventos extremos de cheia, seca e anos regulares. Foi verificado que o sistema responde significativamente a eventos de precipitação. Embora haja solos com diferentes texturas, estas não provocam diferenças significativas nos fatores de recarga do aquífero. O estudo permitiu melhor conhecimento do comportamento da recarga do aquífero aluvial e suas relações com o solo e com os eventos de chuva da região.

PALAVRAS-CHAVE: fator de recarga, água subterrânea, monitoramento.

\section{INTRODUCTION}

The alluvial river valleys, formed by deposition of river sediments and material eroded from the surrounding slopes, are predominantly sandy, and play an important role in supplying the rural population and agricultural use, especially in semiarid regions. This type of formation is of easy

\footnotetext{
${ }^{1}$ Mestre em Engenheira Agrícola, Analista Ambiental, Agência Estadual de Meio Ambiente, CPRH, Garanhuns-PE, Fone: (87) 3761-0697, tafnes.andrade@cprh.pe.gov.br

${ }^{2}$ Engenheira Civil, Prof. Doutor, Departamento de Engenharia Civil, UFPE, Recife-PE, suzanam.ufpe@gmail.com

${ }^{3}$ Engenheiro Civil, Prof. Doutor, Departamento de Engenharia Agricola, UFRPE, Recife-PE, abelardo.montenegro@yahoo.com.br

${ }^{4}$ Mestre em Engenharia Agrícola, Departamento de Engenharia Agrícola, UFRPE, Recife-PE, diogo.borbar@gmail.com

Recebido pelo Conselho Editorial em: 3-1-2012

Aprovado pelo Conselho Editorial em: 18-11-2013
} 
drilling, and is usually in a favorable location regarding recharge. The groundwater levels are close to the surface in this type of aquifer, which have medium to high hydraulic conductivity.

A determining factor regarding alluvial water availability is precipitation. It is necessary that the rains occur in quantity and intensity capable of recharging aquifers so that there is assurance that the dry period offers less negative impacts on the population that uses it. In dry seasons there are decreases in water storage in aquifers, and the recomposition of volume occurs during the rainy season. So, how much water is lost in this system and how it retrieves are key issues for water management (OLIVEIRA et al., 2005).

Quantification of groundwater recharge is a basic prerequisite for an efficient management of aquifers and particularly vital in semiarid regions where such resources are essential for economic development (MELO et al., 2005). GÓMEZ et al. (2010) state that the knowledge of the groundwater recharge is needed in resolving issues related to water quality, ecology and human and environmental well-being, as well as modeling of groundwater flow and contaminant transport. The spatial and temporal variability of recharge is one of the most important issues in hydrological research because of its importance to management of groundwater resources (RABELO \& WENDLAND, 2009; DRIPPS \& BRADBURY, 2010).

The recharge of an aquifer displays variability in space, due to differences that occur in the soil as the water absorption and retention, and in time, due to climatic effects and the exploitation itself (MANZIONE et al., 2007). FORMAGGIO et al. (2009) studied the variability of the unconfined aquifer potentiometric of the Alto Rio Jardim watershed, and concluded through a

spatial multiple regression that the variable that most contributed to variability in potentiometry in the area was soil texture.

There are several methodologies that can be applied to the evaluation of recharge, such as an analysis of hydrograph recession curve, the water balance, the balance of chloride, Darcy's Law applied to the saturated porous medium, and measures of the potentiometric level variation. Among these options, the methodology of varying the level has as its main advantage of simplicity, it is not necessary to consider the transport mechanisms of the water passage in the non-saturated zone, which allows to disregard, for example, the existence of flow preferred paths (BERTOL, 2007). BERTOL (2007) explains that the application of this methodology produces better results in areas with shallow potentiometric level, enabling rapid increases in response to rainfall since deep levels tend not to present a wide variation.

The level variation method uses potentiometric information as effective recharge indicators. It is based on the premise that the increasing of water level is caused by the arrival of recharge to the saturated zone of the aquifer, i.e., whenever there are positive changes in the level it is possible to quantify a recharge (BARRETO et al., 2009). SILVA et al. (2012) used data from the monitoring of the aquifer and specific yield of the aquifer to determine the direct recharge in four recharge areas of aquifers in the Alto Rio Grande region, in the state of Minas Gerais (MG), Brazil, and observed that the presence of forest in the recharge area can excel the slope of the relief, providing more direct recharge. The authors also concluded that this method is consistent for estimating direct recharge.

This study aims to analyze the dynamics of alluvial aquifer recharge in the period of January 2002 to October 2009, and estimate the factor recharge in the alluvial valley formed by the temporary Mimoso stream in the semiarid region of Pernambuco (PE), Brazil, using the water level fluctuation method. Thus, it was used data from the monitoring of the water level in piezometers installed along the alluvial valley and rainfall data recorded at meteorological station also installedin the area. The following hypotheses were proposed: recharging the alluvial aquifer varies with soil texture; recharge is influenced primarily from direct recharge resulting from precipitation. This system is representative of many others that exist in the semiarid region. 


\section{MATERIAL AND METHODS}

The study area is located in the municipality of Pesqueira, in the agreste region the state of Pernambuco, in the Rural Settlement Nossa Senhora do Rosário, located in the Watershed of Ipanema River, between the geographical coordinates $8^{\circ} 15^{\prime}$ and $8^{\circ} 30^{\prime}$ south latitude and $31^{\circ} 45^{\prime}$ and $37^{\circ} 00^{\prime}$ west longitude, and $650 \mathrm{~m}$ of altitude. The average annual rainfall in the area is $730 \mathrm{~mm}$, obtained from the meteorological station of Pesqueira. The potential evapotranspiration estimated by Class A Tank is 1683mm annual (MONTENEGRO \& MONTENEGRO, 2006).

Figure 1 illustrates a schematic map of the alluvial aquifer of the Mimoso Stream, indicating the boundaries of the Nossa Senhora do Rosário Farm. The predominant soil types are Fluvisols, Regosols and Lithosols (CORRÊA \& RIBEIRO 2001). Figure 1 also illustrates the location of piezometers and wells in the valley studied, and the division of the alluvial aquifer in soil classes as presented by MONTENEGRO \& MONTENEGRO (2006), described in Table 1 . In this study the soil of the alluvial valley was divided into two textural classes: loam and sandy loam. The same division was used to group the piezometers according to the predominant texture in the calculation of annual recharge. At Nossa Senhora do RosárioFarm is practiced irrigated agriculture, using the water from community and private wells.

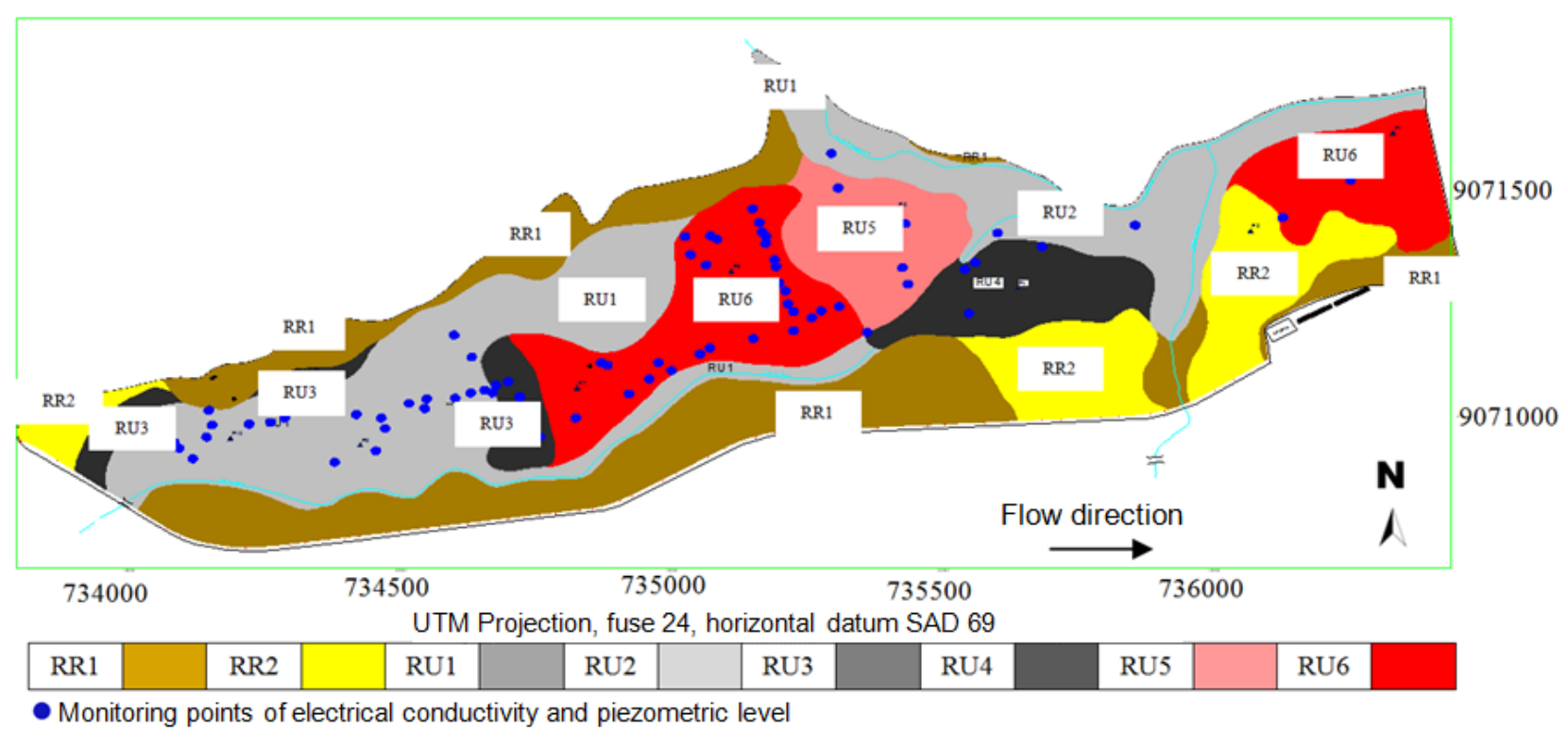

FIGURE 1. Map of main soils in the alluvial valley. Source: CORRÊA \& RIBEIRO (2001). (Classes described in Table 2).

TABLE 1. Description of soil classes in the study area.

\begin{tabular}{ll}
\hline Reference for Figure 1 & \multicolumn{1}{c}{ Soil description } \\
\hline RR1 & $\begin{array}{l}\text { ENTISOL leptic eutrophic + UDORTHENT eutrophic typical, both slightly } \\
\text { wavy } \\
\text { RR2 }\end{array}$ \\
ENTISOL solodic eutrophic, average texture (light), plain relief and slightly \\
wavy \\
FLUVENT eutrophic typical, sandy or average (light) texture / average (light) or \\
sandy moderately drained \\
FLUVENT eutrophic typical, average / average (light) or sandy texture \\
moderately drained \\
RU3 \\
FU4 \\
RU5
\end{tabular}


The studied aquifer has an average thickness of about 10m, about 3km long and 300m wide, a natural topographic slope of approximately $0.3 \%$ ( East-West ), and has on its banks granite and gneiss of crystalline formation. MONTENEGRO et al. (2003) indicate that the average depth of the water table varies between 2.0 and $4.0 \mathrm{~m}$, for the rainy and dry periods, respectively. The hydraulic conductivity varies from $0.02 \mathrm{~m}$.day ${ }^{-1}$ to $187 \mathrm{~m}$.day ${ }^{-1}$, with an average of $28.36 \mathrm{~m}_{\text {.day }}{ }^{-1}$, according to MONTENEGRO et al. (2003).

The study area has a network of 33 wells and 67 piezometers, properly georeferenced. Each piezometer is about $5 \mathrm{~m}$ deep, and $100 \mathrm{~mm}$ in diameter, protected with fabric and gravel filter. Regarding the installed wells, four are communitarian and twenty-nine are private. Monthly data of the monitoring of potentiometric levels between January 2002 and October 2009 were used. This period was selected because it presented continuous time series and involve extremes of high and low rainfall years and also regularity, providing a better understanding of the behavior refill. Table 2 displays the monthly and annual totals of precipitation for the period of January 2002 to December 2009 recorded at meteorological station installed in the study area. Rainfall is distributed non-uniformly, concentrated in the first half (January-July). For purposes of this recharge study, the spatial variability of precipitation in the flood area was not considered. The small size of the study area allowed this approach to study the effect of recharge. The valley has five pluviometers in the study, three manual and two automatic. Readings of the manual pluviometers are being held daily, about eight o'clock in the morning.

TABLE 2. Monthly and yearly rainfall (mm) during the period 2002 to 2009.

\begin{tabular}{crrrrrrrr}
\hline & 2002 & 2003 & 2004 & 2005 & 2006 & 2007 & 2008 & 2009 \\
\hline Jan & 193.5 & 0.0 & 141.0 & 127.5 & 0.0 & 19.2 & 1.9 & 81.8 \\
Feb & 101.0 & 0.0 & 208.0 & 0.0 & 47.0 & 116.3 & 9.6 & 102.9 \\
Mar & 181.0 & 32.0 & 128.0 & 189.7 & 184.0 & 210.0 & 237.6 & 0.0 \\
April & 52.0 & 27.9 & 61.5 & 34.9 & 177.5 & 63.4 & 133.6 & 213.9 \\
May & 59.5 & 46.4 & 92.5 & 122.8 & 82.5 & 123.3 & 159.8 & 211.6 \\
Jun & 114.5 & 41.6 & 232.0 & 124.8 & 158.5 & 51.0 & 0.0 & 47.8 \\
Jul & 44.0 & 47.2 & 95.5 & 35.8 & 69.5 & 55.5 & 92.4 & 0.0 \\
Aug & 31.0 & 5.0 & 90.0 & 130.0 & 32.0 & 55.5 & 63.8 & 89.0 \\
Sept & 6.0 & 34.0 & 11.0 & 0.0 & 47.0 & 25.6 & 1.6 & 17.9 \\
Oct & 0.0 & 13.0 & 0.0 & 0.0 & 0.0 & 0.0 & 54.5 & 18.5 \\
Nov & 4.0 & 10.9 & 14.0 & 0.0 & 6.0 & 3.6 & 68.5 & 15.02 \\
Dec & 26.5 & 0.0 & 0.0 & 122.0 & 0.0 & 0.0 & 0.0 & 49.30 \\
\hline Total & 813 & 258 & 1073.5 & 887.5 & 804 & 723.4 & 823.3 & 847.72 \\
\hline
\end{tabular}

The method of fluctuation of the water level was used to assess the aquifer recharge. This methodology was adopted by MONTENEGRO et al. (2003), using monthly data of the water level in the piezometers, together with the local rainfall. Taking the monthly rate of change in the water level and assuming a storage coefficient, $\mathrm{S}$, of 0.10 to the area, obtained by pumping tests during the construction of wells (CISAGRO, 1991), it is possible to identify the months when there are alluvial piezometric recoveries, which enables the evaluation of the recharge $R[\mathrm{~L}]$ by the following equation [eq.(1)]: where,

$$
R=S(d h / d t)=S(\Delta h / \Delta t)
$$

$$
\begin{aligned}
& \Delta t=1, \text { since it is a monthly recharge, it is understood that: } \\
& R=S . \Delta h
\end{aligned}
$$

where, 
$\Delta h[\mathrm{~L}]$ - represents the variation of the potentiometric level of the water table between the following months, and $\mathrm{S}$ is the aquifer storage coefficient.

When the monthly recharge at each point was calculated, it was then divided by the same monthly rainfall, thus obtaining the factor of recharging. The recharge factors were classified according to the predominant soil texture where the piezometers are installed, specifically in soils of foam and sandy loam textures. The factors underwent the test of difference between averages in order to check for differences in recharges that may occur in soils of contrasting texture. Student's ttest was used in this study.

To observe the pattern of recharge in different soil types, it was used data from January 2008 to October 2009, taking a representative of each piezometer spot of soil. The criterion used in selecting the piezometer was the highest number of months in the period monitored. The following piezometers were selected: $\mathrm{Pz}$ 3.11d (RR1), Pz 4.10 (RU1), Pz P(2) (RU2), Pz 11 (RU3), Pz 7.2 (RU4), Pz 3.3 (RU5) and Pz 3.18 (RU6).

\section{RESULTS AND DISCUSSION}

Figure 2 shows the average temporal fluctuations of piezometers installed along the alluvial aquifer, and the total rainfall in each month. It can be observed that the water level shows a consistent response to rainfall events, indicating the occurrence of recharge to the groundwater table. In 2003, there was a great lowering of the potentiometric level in the valley due to the occurrence of an atypical dry year, when the lowest average levels in relation to the soil surface were observed. Rainfall was well below the historical average for the region, which, according to MONTENEGRO \& MONTENEGRO (2006), is 750mm. In this year, the total rainfall was only $258 \mathrm{~mm}$. There was a rapid recovery of the groundwater levels with rainfall occurring in January 2004, according to the recharge of groundwater. The significant precipitation events of those systems responses were described by ANDRADE et al. (2009). Other alluvial aquifers, as described by CHOI et al. (2010) and BURTE et al. (2005) also show rapid recovery response of water levels when there are precipitation events.

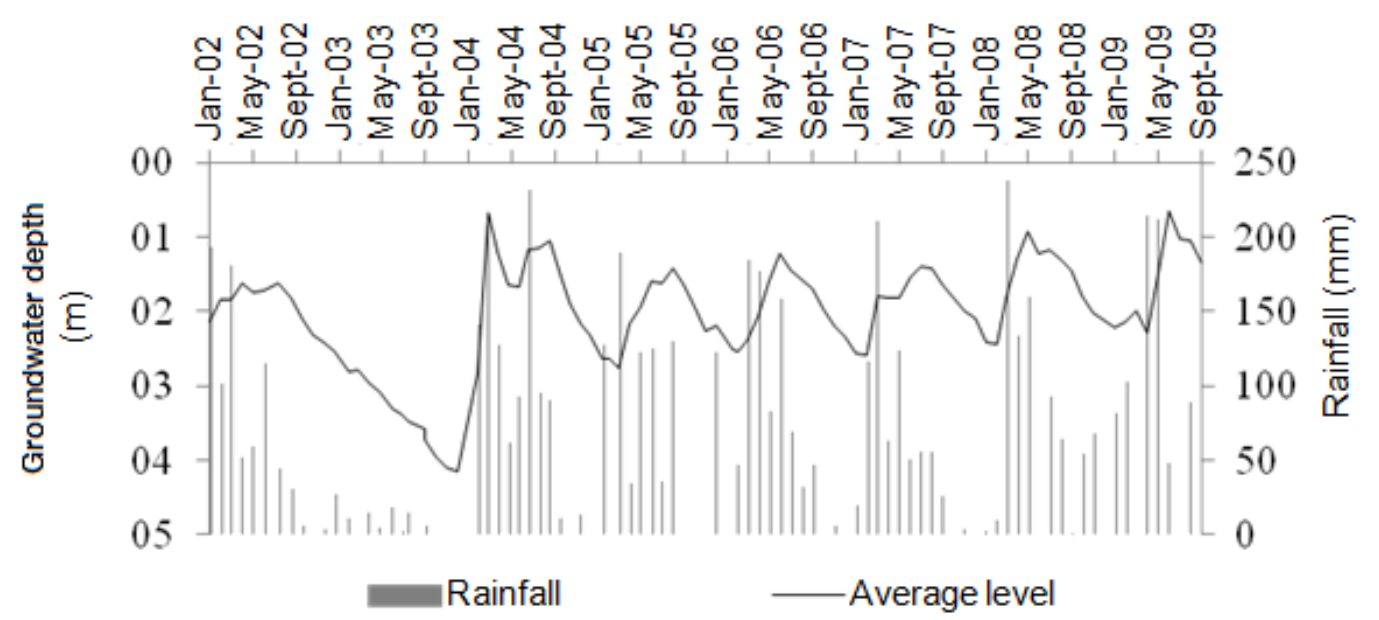

FIGURE 2. Variation of monthly average groundwater depth and rainfall.

Regarding the rainfall, it can be seen the occurrence of two distinct periods, a rainy one (January to July) and a dry one (August to December). Analyzing Figure 2, it is possible to see that low rainfall magnitudes tend not contribute to groundwater recharge. Only monthly rainfall of approximately $100 \mathrm{~mm}$ or greater than this value promoted recharge in the aquifer. This fact was also observed in other semiarid alluvial valleys, such as the karst aquifer of Irecê, in the state of Bahia (BA) (RAMOS et al., 2007) and Forquilha Valley, Quixeramobim, in the state of Ceará (CE) (BURTE et al., 2005). 
Figure 3 displays the confidence interval for the average depth of the water level in piezometers installed in loam and sandy loam soils, based on the sample standard deviation, with significance level of 5\%. The rainfall that generated recharge occurred in the periods from January to April and May to July 2002, December 2003 to February 2004, May to August 2004, March to August 2005, January to June 2006, February to July 2007, February to May and June to July 2008, January to March and April to July 2009. No recharge in the water table was observed during the year 2003. It is possible to note the similarity of the fluctuation of the table in soils of loam and sandy loam textures, for the same period.

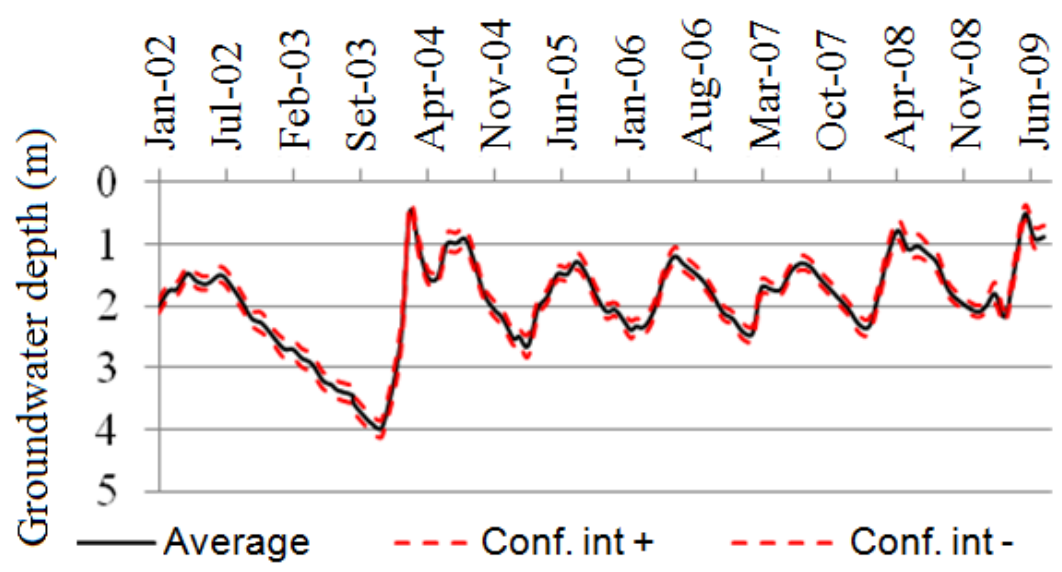

FIGURE 3. Confidence interval for the average piezometric fluctuations. (A) loam soil; (B) sandy loam soil.

Using eq.(2), the annual amount of recharge to the alluvial valley obtained by the arithmetic average of the recharge occurred in each piezometer was calculated. The estimates of annual recharge generated by the fluctuation of the water level method are summarized in Table 3. In 2003, an atypical dry year, there was no recharge in the aquifer. The year of 2004 presented the highest recharge for the period studied, $289.90 \mathrm{~mm} \mathrm{yr}^{-1}$, about $27 \%$ of the precipitation. Years with similar annual total rainfall, as 2002 and 2006, whose difference was only $9 \mathrm{~mm} . \mathrm{yr}^{-1}$, recorded a difference of more than $40 \mathrm{~mm}_{\mathrm{yr}}{ }^{-1}$ in aquifer recharge. The years of 2005 and 2007 showed a difference in total rainfall of over $160 \mathrm{~mm}_{\text {.yr }}{ }^{-1}$ and a difference of just over $1 \mathrm{~mm} . \mathrm{yr}^{-1}$ in recharge. One possible explanation for this behavior may be in the temporal distribution of rainfall during the year. That is, the way rainfall is distributed seems to be more important in generating recharge than the actual total amount.

TABLE 3. Annual rainfall and recharge during the period from 2002 to 2009.

\begin{tabular}{ccc}
\hline Year & Rainfall $\left(\mathrm{mm}\right.$. year $\left.^{-1}\right)$ & Average recharge $\left(\mathrm{mm} . \mathrm{year}^{-1}\right)$ \\
\hline 2002 & 813.00 & 67.22 \\
2003 & 258.00 & 0.00 \\
2004 & 1073.50 & 289.90 \\
2005 & 887.50 & 133.32 \\
2006 & 804.00 & 108.81 \\
2007 & 723.40 & 118.48 \\
2008 & 823.43 & 161.48 \\
2009 & 847.72 & 176.13 \\
\hline
\end{tabular}

RABELO \& WENDLAND (2009) estimated the annual recharge of the Guarani Aquifer in $297.6 \mathrm{~mm}$ for a rainfall of $1,371 \mathrm{~mm}$, through computer simulation. BARRETO et al. (2009), using the method of variation of the groundwater level, estimated the average annual recharge of the Onça stream watershed aquifer, which also is part of the Guarani Aquifer, between 313 and 407mm, with an average rainfall of $1,410 \mathrm{~mm}$. Although the formation of the Guarani Aquifer is different from 
the aquifer studied, besides the difference between rainfalls of the areas, it is possible to observe the consistency among the order of magnitude of the values.

In order to verify the existence of differences between recharges occurring in sandy loam and foam soils, recharges of the years 2008 and 2009 were analyzed through their recharge factors. This period can be considered representative due to the cyclical behavior of the dynamics of change in groundwater levels, in which recharge is based.

In 2008, the confidence interval of the recharge factor, based on 25 samples of a sandy loam soil and 64 of loam soil, both with significance level of 5\%, was [0.262, 0.411] and [0.261, 0.363], while for recharges in 2009, the confidence interval was [0.221, 0.350] for the sandy foam soil, and $[0.284,0.366]$ for the foam soil, obtained from 24 and 60 samples, respectively.

To test the statistical difference between averages, the Student's t-test was used. Before submitting the data to this test, their normality was verified, using the Kolmogorov-Smirnov test, whose result is shown in Table 4.

TABLE 4. Results of Kolmogorov-Smirnov test applied to recharge factors to the years 2008 and 2009.

\begin{tabular}{ccccc}
\hline & \multicolumn{2}{c}{2008} & \multicolumn{2}{c}{2009} \\
\hline & Sandy loam & Loam & Sandy loam & Loam \\
\hline D (KS)* & 0.221 & 0.157 & 0.188 & 0.077 \\
KS $^{* *}$ & 0.272 & 0.170 & 0.278 & 0.176 \\
Number of samples & 25 & 64 & 24 & 60
\end{tabular}

*D $(K S)=\max [F(X)-G(X)]$, where $F(X)=P(X<x)$ and $G(X)$ are the accumulated relative frequencies of the observed values.

$* *$ Normal distribution by the KS test with a probability level of $5 \%$.

The result of the Student's t-test is shown in Table 5. The values of the t statistic ( 0.551 in 2008, and -1.068 in 2009) were below the two-tailed critical t. Thus, the hypothesis of equality between the means of recharging factors obtained under different conditions of the soil texture should be accepted. That is, although there are soils with different textures, they do not cause significant differences in the aquifer recharge factors. This observation may support the hypothesis raised by ALBUQUERQUE et al. (2008), who suggest that the diffuse recharge does not constitute the main mechanism for recharging the alluvial valley, but the lateral recharge between the slopes and the valley, together with the river-aquifer interaction, suggesting the existence of semiconfinement regions in the aquifer.

TABLE 5. Student's t-test: two samples assuming different variances, as applied to recharge factors.

\begin{tabular}{|c|c|c|c|c|}
\hline & \multicolumn{2}{|c|}{2008} & \multicolumn{2}{|c|}{2009} \\
\hline & Sandy loam & Loam & Sandy loam & Loam \\
\hline Average & 0.3368 & 0.3125 & 0.2854 & 0.3252 \\
\hline Variance & 0.0327 & 0.0417 & 0.0233 & 0.0252 \\
\hline Observations & 25 & 64 & 24 & 60 \\
\hline gl & \multirow{2}{*}{\multicolumn{2}{|c|}{$\begin{array}{c}49 \\
0.551\end{array}$}} & \multicolumn{2}{|c|}{44} \\
\hline Stat $\mathrm{t}$ & & & \multirow{2}{*}{\multicolumn{2}{|c|}{$\begin{array}{c}-1.068 \\
2.015\end{array}$}} \\
\hline Two-tailed critical t & \multicolumn{2}{|c|}{2.010} & & \\
\hline
\end{tabular}

$5 \%$ of significance.

The variation of the potentiometric level of the aquifer as a function of rainfall, using the piezometer with the highest number of months monitored in each zone of soil is presented in Figure 4. No changes were observed in the high-level behavior between different potentiometric piezometers. The greatest variation was observed in the Pz 4.10 (RU1), $2.18 \mathrm{~m}$, and the lower in Pz P(2) (RU2), $1.07 \mathrm{~m}$. This result is consistent with those from the analysis of the recharge factor, which indicated no significant difference between the different soil textures, and the study of MONTENEGRO et al. 
(2001), which indicates that there is no explicit correlation between the water level and soil pedological class, in the alluvial valley studied.

A.

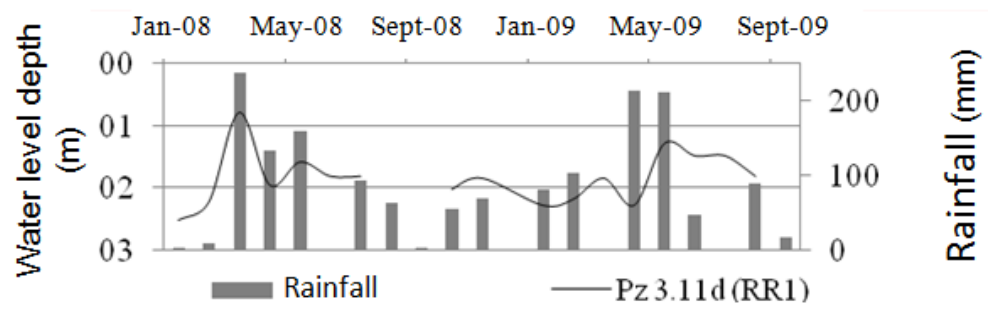

B.
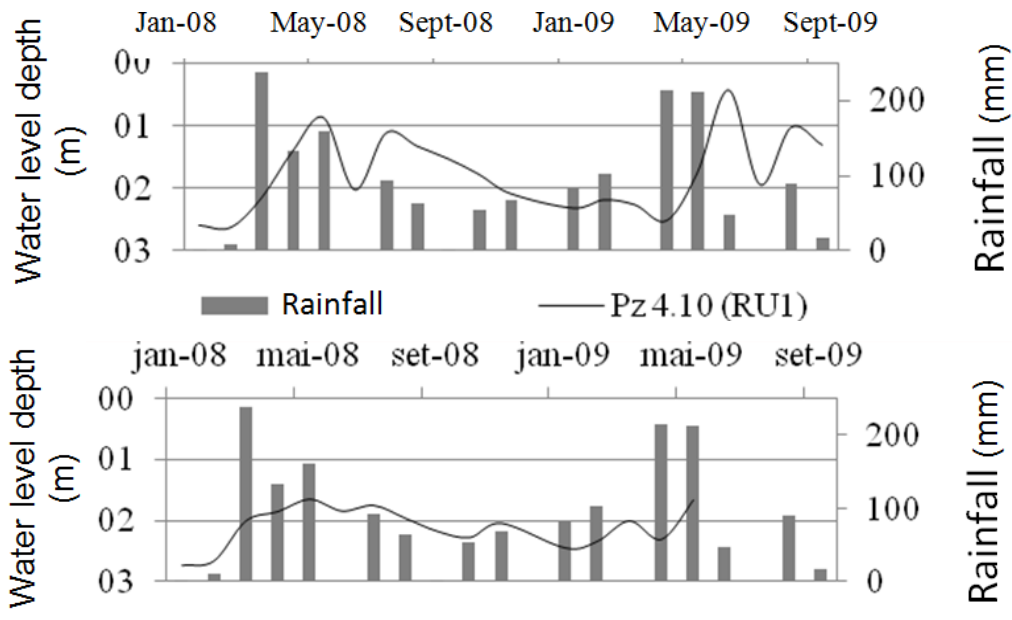

C.

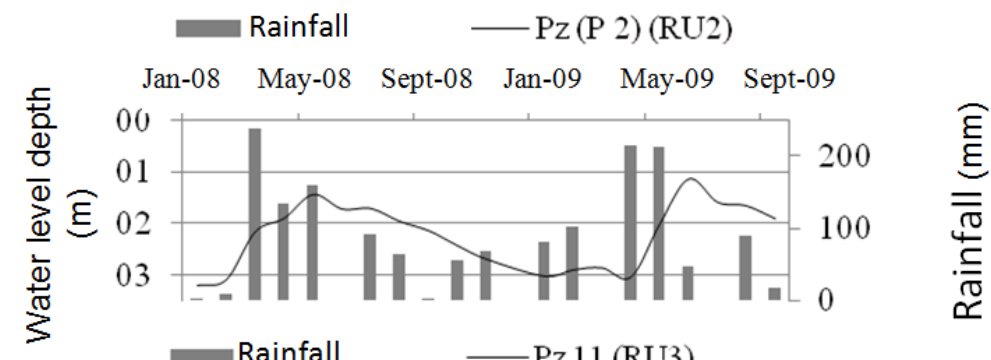

D.

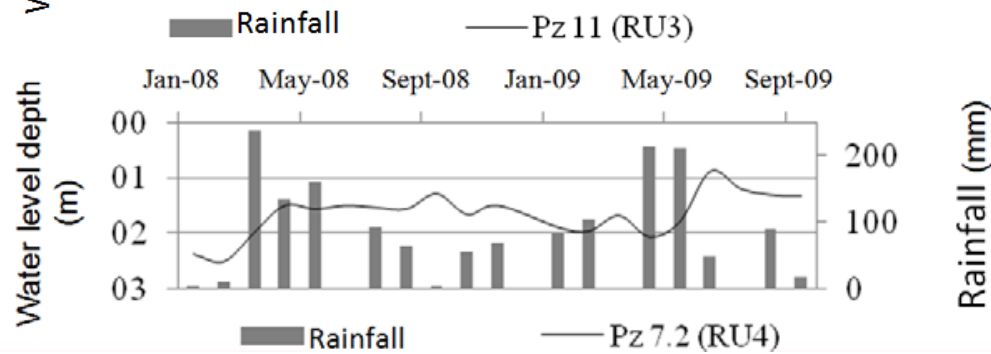

E.

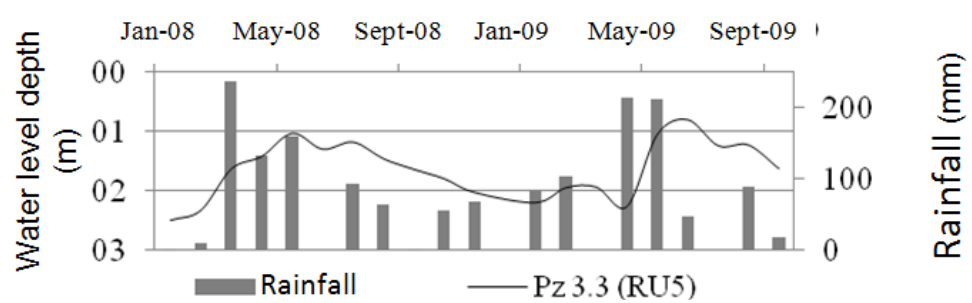

F.

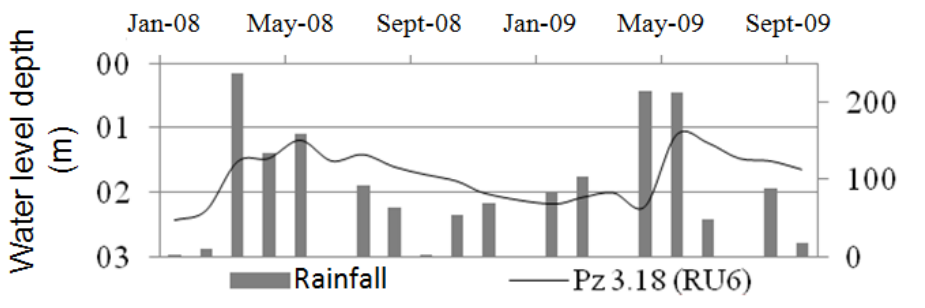

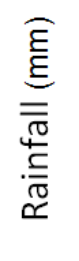

FIGURE 4. Temporal variation of precipitation and the aquifer potentiometric levels. (A) RR1 Entisol + Udorthent; (B) RU1 Entisol; (C) RU2 Fluvent; (D) RU3 Fluvent; (E) RU4 Fluvent; (F) RU5 Fluvent; (G) RU6 Fluvent. 
Indeed, it is possible to notice small differences. Among them it is worth mentioning recharges occurring in an RR1 soil spot, which is an Entisol + Udorthent, i.e., little evolved soil and presenting rock fragments that originated the soil (EMBRAPA, 2006). These soils laterally bound the valley (Figure 1), and are at the base of the slopes. Recharges occurred in this region of the valley is the first to return to rainfall (Figure 4). MONTENEGRO et al. (2001) indicate that there is a significant contribution arising from the lateral flow, which originates from the slopes. The fact of the RR1 soil spot is in the base of the slopes means that both direct recharges and those caused by lateral flow are present. REDDY et al. (2009) also observed a considerable lateral flow in the slopes to recharge the groundwater of the Wailapally Basin, as well as studies of KREBS \& POSSA (2008) also noted the presence of lateral flow from the slopes of the alluvial valley of the Araranguá River, in the state of Santa Catarina.

The piezometer installed in the RU3 spot is the one that presents the deeper water level, indicating that the layer of impervious is also at a greater depth. The texture of this soil is average with moderate drainage. On the other hand, the piezometer water levels of RU5 and RU6 spots are closest to the surface. In these, the soil has medium texture with high silt values, and also has a superficial impervious layer, which hinders the natural drainage of the valley.

Table 6 presents the recharge, rainfall and recharging period occurred between 2008 and 2009 in the seven soil spots. In general, recharges tend to be concentrated in the months from January to July. The larger recharges were observed in the RR1 and RU2 soil spots, in 2008, and in the RU1, RU5 and RU3 spots in 2009. The RU4 and RU6 soil spots presented nearly identical recharges in both years. A delay is observed in the most significant recharges in 2009, compared with 2008. This is because the rains of large magnitudes and ability to promote recharges had its beginning from the month of March in 2008, and from April 2009 (Table 1).

TABLE 6. Characterization of recharge occurring in the years 2008 and 2009 in seven different soil spots.

\begin{tabular}{|c|c|c|c|c|c|}
\hline \multicolumn{3}{|c|}{2008} & \multicolumn{3}{|c|}{2009} \\
\hline $\begin{array}{l}\text { Recharge } \\
\text { period }\end{array}$ & $\begin{array}{l}\text { Recharge } \\
\text { (mm) }\end{array}$ & $\begin{array}{l}\text { Total rainfall in the } \\
\text { period (mm) }\end{array}$ & $\begin{array}{l}\text { Recharge } \\
\text { period }\end{array}$ & $\begin{array}{l}\text { Recharge } \\
(\mathrm{mm})\end{array}$ & $\begin{array}{l}\text { Total rainfall in the } \\
\text { period (mm) }\end{array}$ \\
\hline jan - mar & 174 & 249.16 & jan - mar & 44 & 184.75 \\
\hline $\overrightarrow{\widetilde{\alpha}}$ apr - may & 37 & 293.44 & apr - may & 100 & 425.53 \\
\hline oct - nov & 18 & 122.94 & & & \\
\hline feb - may & 174 & 540.67 & jan - feb & 13 & 184.75 \\
\hline$\underset{ح}{\curvearrowright}$ jun - jul & 9 & 92.42 & mar - jun & 182 & 473.38 \\
\hline oct - nov & 23 & 122.94 & jul - aug & 91 & 88.96 \\
\hline v jan - may & 107 & 542.60 & jan - mar & 44 & 184.75 \\
\hline$\underset{\sim}{\widetilde{\gamma}}$ jun - jul & 9 & 92.42 & apr - may & 64 & 425.53 \\
\hline oct - nov & 23 & 122.94 & & & \\
\hline m jan - may & 176 & 542.60 & jan - mar & 16 & 184.75 \\
\hline$\widetilde{\simeq}$ jun - jul & 1 & 92.42 & apr - jun & 190 & 473.38 \\
\hline feb - apr & 102 & 380.86 & feb - mar & 28 & 102.92 \\
\hline$\$$ may - jun & 7 & 159.81 & apr - jun & 118 & 473.38 \\
\hline aug - sept & 28 & 65.47 & & & \\
\hline oct - nov & 17 & 122.94 & & & \\
\hline \multirow{2}{*}{$\begin{array}{lc}\mathscr{\rho} & \text { feb - may } \\
\Omega & \text { jun - jul }\end{array}$} & 130 & 540.67 & jan - mar & 26 & 184.75 \\
\hline & 12 & 92.42 & apr - jun & 147 & 473.38 \\
\hline \multirow{2}{*}{$\begin{array}{lc} & \text { jan - may } \\
\Omega & \text { jun - jul }\end{array}$} & 123 & 542.60 & jan - mar & 17 & 184.75 \\
\hline & 10 & 92.42 & apr - may & 110 & 425.53 \\
\hline
\end{tabular}




\section{CONCLUSIONS}

The monitoring of rainfall and groundwater level enabled the verification that the studied alluvial system presents consistent response to rainfall events.

It was found that although there are soils with different textures, they do not cause significant differences in the factors of the aquifer recharge.

The study provided a better understanding of the behavior of the recharge of the aquifer and its relationship with the soil and the rainfall events in the region.

\section{ACKNOWLEDGEMENTS}

To National Council for Scientific and Technological Development - CNPq, for granting the Masters Scholarships, IC and PQ and necessary resources for the development of this study. To Federal Rural University of Pernambuco for the logistics and support during the study. To FINEP for the support to the study project.

\section{REFERENCES}

ALBUQUERQUE, C. G. de; PONCIANO, I. de M.; MONTENEGRO, A. A. de A.; MONTENEGRO, S. M. G. L. Dinâmica de potenciometria e salinidade de aluvião no semi-árido Pernambucano. In: CONGRESSO BRASILEIRO DE ÁGUAS SUBTERRÂNEAS, 15², 2008, Natal. Anais...

ANDRADE, T. S.; SANTOS, E. S.; MONTENEGRO S. M. G. L.; ALBUQUERQUE, C. G.; MONTENEGRO, A. A. A. Monitoramento do nível freático em solo de aluvião em Pesqueira - PE. In: CONGRESSO BRASILEIRO DE ENGENHARIA AGRÍCOLA, 38., 2009, Juazeiro. Anais... Jaboticabal: SBEA, 2009. CD-ROM.

BARRETO, C. E. A. G.; WENDLAND, E.; MARCUZZO, F. F. N. Estimativa da evapotranspiração a partir de variação de nível estático de aquífero. Engenharia Agrícola, v.29, n.1, p.52-61, 2009.

BERTOL, G. A. Avaliação da recarga anual no aquífero Bauru no município de Araguari. 2007 111 f. Dissertação (Mestrado) - Universidade Federal de Minas Gerais, Belo Horizonte, 2007.

BURTE, J.; COUDRAIN, A.; FRISCHKORN, H.; CHAFFAUT, I.; KOSUTH, P. Impacts anthropiques sur les termes du bilan hydrologique d'un aquifére alluvial dans le Nordeste semiaride, Brasil. Hydrological Sciences, Oxford, v.50, p.95 - 110, 2005.

CHOI, BYOUNG-YOUNG; YUN, SEONG-TAEK; MAYER, B., CHAE, GI-TAK, KYOUNG-HO KIM; KIM, KANGJOO; KOH, YONG-KWON. Identification of groundwater recharge sources and processes in a heterogeneous alluvial aquifer: results from multi-level monitoring of hydrochemistry and environmental isotopes in a riverside agricultural area in Korea. Hydrological Processes, Chichester, v.24, p.317-330. 2010.

CISAGRO - Companhia Integrada de Servicos Agropecuários. Projeto de irrigação da Fazenda Nossa Senhora do Rosário, Pesqueira. Recife, 1991.

CORRÊA, M.M.; RIBEIRO, M.R. Levantamento detalhado de solos da Fazenda Nossa Senhora do Rosário (Pesqueira - PE). Recife: UFRPE/UFPE/CNPQ/BNB. (2001. 35p. Relatório Técnico).

DRIPPS, W. R.; BRADBURY, K. R. The spatial and temporal variability of groundwater recharge in a forested basin in northern Wisconsin. Hydrological Processes, Chichester, v.24, p.383-392, 2010.

EMBRAPA - Empresa Brasileira de Pesquisa Agropecuária. Centro Nacional de Pesquisa de Solos. Sistema brasileiro de classificação de solos. 2.ed. Rio de Janeiro, 2006. 306p 
FORMAGGIO, L. F.; CAMPOS, J. E. G.; AMARAL, B. D. Estudo da variabilidade da potenciometria em aquíferos freáticos com auxílio de regressão múltipla espacial. Revista Brasileira de Geociências, São Paulo, v.39, p.101-111, 2009.

GÓMEZ, A. A.; RODRÍGUEZ, L. B.; VIVES, L. S. The Guarani Aquifer System: estimation of recharge along the Uruguay-Brazil border. Hydrogeology Journal, New York, n. 18, p.1667-1684, 2010.

KREBS, A. S. J.; POSSA, M. V. O papel da hidrogeologia como instrumento de gestão ambiental na mineração de carvão. Carvão Brasileiro: Tecnologia e meio ambiente, v.1, p.109-127. 2008.

MANZIONE, R. L.; DRUCK, S.; CÂMARA, G. E.; MONTEIRO, A. M. V. Modelagem de incertezas na análise espaço-temporal dos níveis freáticos em uma bacia hidrográfica. Revista Pesquisa Agropecuária Brasileira, Rio de Janeiro, v.42, p.25-34, 2007.

MELO, J. G.; STEIN, P.; VASCONCELOS, M. B.; SILVA, F. H. R. Fatores condicionantes na recarga do aquífero Açu na borda sudoeste da bacia potiguar (RN). Revista Águas Subterrâneas, v.19, p.105-122, 2005 .

MONTENEGRO, A. A. A.; MONTENEGRO, S. M. G. L. Variabilidade espacial de classes de textura, salinidade e condutividade hidráulica de solos em planície aluvial. Revista Brasileira de Engenharia Agrícola e Ambiental, Porto Alegre, v.10, p.30-37, 2006.

MONTENEGRO, S. M. G. L.; MONTENEGRO, A. A. A.; MACKAY, R.; OLIVEIRA, A. S. C. Dinâmica hidro-salina em aquífero aluvial utilizado para agricultura irrigada familiar em região semi-árida. Revista Brasileira de Recursos Hídricos, v.8, p.85-92, 2003.

MONTENEGRO, S. M. G. L.; MONTENEGRO, A. A. A.; RIBEIRO, M. R.; CORRÊA, M. M.; ALMEIDA, T. A.; MAIA, F. M. V. L. Análise da variabilidade espacial da salinidade em área irrigada e do nível d'água em aluvião sob uso agrícola na região semi- árida do nordeste brasileiro. In.: SIMPÓSIO BRASILEIRO DE RECURSOS HÍDRICOS, 14., 2011, Aracaju. Anais... Porto Alegre: ABRH, 2001. CD - ROM.

OLIVEIRA, R. S.; BEZERRA, L.; DAVIDSON, E. A.; PINTO, F.; KLINK, C. A.; NEPSTAD, D. C.; MOREIRA, A. Deep root function in soil water dynamics in cerrado savannas of central Brazil. Functional Ecology, Oxford, v.19, p.574-581, 2005.

RABELO, J. L.; WENDLAND, E. Assessment of groundwater recharge and water fluxes of the Guarani Aquifer System, Brazil. Hydrogeology Journal, New York, v. 17, p. 1733-1748, 2009.

RAMOS, S. O.; ARAÚJO, H. A.; LEAL, L. R. B.; LUZ, J. A. G.; DUTTON, A. R.Variação temporal do nível freático do aquífero cárstico de Irecê - Bahia: Contribuição para uso e gestão das águas subterrâneas no semiárido. Revista Brasileira de Geociências, São Paulo, n. 37, p. 227-233, 2007.

REDDY, D. V.; NAGABHUSHANAM, P.; SUKHIJA, B. S.; REDDY, A. G. S. Understanding hydrological processes in a highly stressed granitic aquifer in southern India. Hydrological Processes, Chichester, n.23, p.1282 - 1294, 2009.

SILVA, L. A.; SILVA, A. M.; COELHO, G.; MELLO, C. R.; PEREIRA, D. R. Groundwater recharge estimate at Alto Rio Grande - MG watershed. Engenharia Agrícola, Jaboticabal, v.32, n.6, p.1097-1108, 2012. 